\title{
Penerapan Media Boneka Tangan dalam Keterampilan Berbicara Siswa Kelas IIIb MI At-Thayyibah
}

\author{
Khairunnisa ${ }^{1,}$ Dina Aryanti ${ }^{2}$ \\ Jurusan PGMI Fakultas Tarbiyah dan Keguruan UIN Antasari Banjarmasin \\ Email: annisa@uin-antasari.ac.id
}

\begin{abstract}
The discussion aims to know the implementation of hand puppet and its impact to third grade (III B) students speaking skill on Bahasa Indonesia course at MI At-Thayyibah Kecamatan Gambut. This is quantitative research with pre experiment method. The subject are all students of IIIB which about 22 people. Researchers found out that: 1) the implementation of hand puppet in Bahasa Indonesia Course was going well, we can see from planning, teacher and students activities, and they response to the media which was seen from their attention, enthusiasm, spirit, activeness, understanding material, and teamwork. The learners get new experience to enrich speaking skill through story-telling activity; 2) there was an significant impact from hand puppet implementation to students speaking skill on Bahasa Indonesia Course at MI At-Thayyibah Kecamatan Gambut.
\end{abstract}

Key Words: implementation; hand puppet; speaking skill.

\begin{abstract}
ABSTRAK
Pembahasan ini bertujuan untuk mengetahui bagaimana penerapan media boneka tangan dan pengaruhnya terhadap keterampilan berbicara pada mata pelajaran Bahasa Indonesia siswa kelas III B di MI At-Thayyibah Kecamatan Gambut. Penelitian ini merupakan penelitian kuantitatif dengan metode pra-experimen. Subjeknya adalah semua siswa kelas IIIB berjumlah 22 orang. Peneliti menemukan bahwa: 1) Penerapan media boneka tangan pada mata pelajaran Bahasa Indonesia terlaksana dengan baik, terlihat dari perencanaan, aktiviatas siswa dan guru, serta respon siswa terhadap media yang ditunjukkan oleh perhatian, antusias, semangat, keaktifan, memahami materi, kerjasama kelompok. Siswa memperoleh pengalaman baru dalam meningkatkan keterampilan berbicara melalui kegiatan bercerita. 2) Terdapat pengaruh yang signifikan penerapan media boneka tangan terhadap keterampilan berbicara siswa pada mata pelajaran Bahasa Indonesia di MI At-Thayyibah Kecamatan Gambut.
\end{abstract}

Kata Kunci : penerapan; media boneka tangan; keterambilan berbicara.

\section{PENDAHULUAN}

Mata pelajaran bahasa Indonesia bertujuan agar siswa memiliki berbagai kemampuan, seperti: berkomunikasi secara efektif dan efisien sesuai etika yang baik secara lisan maupun tulis; menghargai dan bangga menggunakan bahasa Indonesia; memahami dan menggunakannya dengan tepat; untuk meningkatkan kemampuan intelektual serta kematangan emosional dan sosial; menikmati dan memanfaatkan karya sastra untuk memperluas wawasan; memperhalus budi pekerti serta meningkatkan pengetahuan dan kemampuan berbahasa; menghargai dan membanggakan sebagai khazanah budaya dan intelektual manusia Indonesia (Ibrahim, 2012).

Kemampuan berbicara dan membaca merupakan bagian dari keempat aspek keterampilan berbahasa yang diajarkan pada mata pelajaran Bahasa Indonesia. Kemampuan berbicara dan membaca ini juga sangat perlu ditumbuhkan pada anak sejak dini. Semakin dini dikembangkan, tentu diharapkan hasilnya akan semakin optimal. Disamping itu adanya peran orang tua dan guru memiliki peran penting untuk meningkatkan keterampilan berbicara.

Linguis berkata bahwa speaking is language. Berbicara adalah suatu keterampilan berbahasa yang berkembang pada kehidupan siswa, yang didahului oleh keterampilan 
menyimak, dan pada masa tersebutlah berbicara atau berujar dipelajari (Tarigan, 2008:3). Pembelajaran keterampilan berbicara pada jenjang sekolah dasar atau madrasah ibtidaiyah merupakan tantangan untuk peningkatan kompetensi berbicara siswa. Mereka diharapkan dapat menyerap aspek-aspek dasar keterampilan berbicara untuk bekal ke jenjang yang lebih tinggi atau memiliki keterampilan berbicara yang baik.

Tujuan pembelajaran pada aspek berbicara di kelas III semester genap adalah setelah mempelajari materi diharapkan siswa dapat menceritakan peristiwa yang pernah dialami, dilihat, atau didengar dengan bercerita. Adapun standar kompetensi dan kompetensi dasar sebagai berikut.

1. Standar Kompetensi (SK), yaitu: Mengungkapkan pikiran, perasaan, dan pengalaman secara lisan dengan bertelepon dan bercerita.

2. Kompetensi Dasar (KD), yaitu:

a. Melakukan percakapan melalui telepon/alat komunikasi sederhana dengan menggunakan kalimat ringkas serta mengetahui pengertian bercerita

b. Menceritakan peristiwa yang pernah dialami, dilihat, atau didengar.

Keterampilan berbicara bisa diasah melalui kegiatan bercerita. Bercerita adalah suatu kegiatan yang dilakukan seseorang secara lisan kepada orang lain dengan alat atau tanpa alat tentang apa yang harus disampaikan dalam bentuk pesan, informasi atau hanya sebuah cerita dogeng untuk di dengarkan dengan rasa menyenangkan. Langkah-langkah bercerita: yaitu a) menentukan topik, b) menyusun kerangka cerita, c) mengembangkan kerangka cerita, dan d) menyusun teks cerita.

Di tingkat sekolah dasar kegiaan ini memerlukan kesabaran karena masih sedikit sekali siswa yang berani tampil dalam membawakan cerita, padahal kita tahu bahwa cerita-cerita di negeri kita cukup banyak. Oleh karena itu, keterampilan berbicara melalui bercerita dalam pembelajaran perlu dikembangkan dengan memperhatikan unsur-unsur diantaranya: ucapan (vokal); suara; ekspresi; penampilan; penghayatan dan masih ada pendukung lain, misalnya media/ alat peraga yang berwujud boneka, gambar, atau lukisan, cerita secara bergantian dan lain sebagainya (Chalimah, 2008:14).

Media adalah segala sesuatu yang dapat digunakan untuk menyalurkan pesan dan merangsang terjadinya proses belajar pada si pembelajar (Aqib, 2013:50). Salah satu media yang dapat digunakan sebagai alternatif media pembelajaran bahasa Indonesia untuk meningkatkan pembelajarannya adalah media Boneka Tangan. Media boneka tangan adalah media alat bantu yang digunakan baik guru atau siswa dalam kegiatan pembelajaran, yang terbuat dari potongan kain flanel, katun, kaos tangan, kaos kaki, dan sebagainya yang dibentuk atau dihias sedemikian rupa sehingga dapat ditampikan menjadi beragam tokoh dengan karakter masing-masing. Dinamakan boneka tangan karena para pemain guru, siswa, atau orang tua dimainkan dengan cara memasukkan tangan ke dalam boneka (Sulianto, 2014:94)

Rambu-rambu dalam memainkan boneka tangan sebelum memulai kegiatan bercerita: yaitu, tanpa panggung (boneka cukup dua buah, cara memainkan boneka harus tepat jangan sampai lepas, cerita yang dibawakan cukup, intonasi wajib diperhatikan, dan waktu saat bercerita.Cara menggunakan boneka tangan saat kegiatan bercerita: yaitu, dengan memasukkan tangan ke dalam boneka kemudia jari tangan bisa dijadikan pendukung gerakan tangan dan kepala boneka (Darmadi \& Nirbaya, 2008:79).

Boneka sebagai media cerita memiliki banyak kelebihan dan keuntungan. Anak-anak pada umumnya menyukai boneka, sehingga cerita yang dituturkan lewat boneka jelas akan mengundang minat dan perhatiannya. Siswa juga dapat terlibat dalam permainan boneka dan ikut untuk memainkan boneka. Hal ini berarti boneka bisa menjadi pengalih perhatian sekaligus media untuk berekspresi atau menyatakan perasaannya. Bahkan boneka bisa 
mendorong tumbuhnya fantasi atau imajinasi anak (Sulianto, 2014:95). Kelebihan menggunakan boneka tangan sebagai media pembelajaran adalah sebagai berikut.

1. Efisien terhadap waktu, tempat, biaya, dan persiapan.

2. Tidak memerlukan keterampilan yang rumit.

3. Dapat mengembangkan imajinasi dan aktivitas siswa dalam suasana gembira (Sulianto, 2014:97).

Dari penjelasan tersebut dapat ditarik sebuah kesimpulan bahwa boneka tangan berfungsi sebagai media yang patut diperhitungkan dengan adanya perantara yang digunakan untuk melibatkan siswa dalam keterampilan berbicara dengan kegiatan bercerita agar lebih aktif dan siswa juga mampu mengungkapkan isi pembelajaran dengan media boneka tangan, tidak hanya itu siswa mungkin lebih tertarik untuk memainkannya dengan media boneka tangan siswa dapat memiliki keterampilan berbicara yang ia tuangkan dengan berekspresi bercerita, dalam menyatakan perasaannya.

Berdasarkan hasil observasi yang telah dilakukan peneliti di MI At-Thayyibah Kecamatan Gambut diketahui bahwa pada mata pelajaran bahasa Indonesia di kelas IIIB masih banyak siswa yang kurang memiliki keterampilan dalam aspek berbicara dan membaca, hal ini ditunjukkan dan terlihat jelas dari minimnya komunikasi yang terjalin antarsiswa, dan saat pembelajaran berlangsung siswa terlihat pendiam dan kurang aktif, siswa tidak bebas mengungkapkan ide atau pun gagasan pemikirannya dengan nyaman.

Melihat dari faktor di atas harus ada pendongkrak yang dapat membuat siswa tidak hanya termotivasi, namun juga terlibat dalam proses pembelajaran. Melalui permainan boneka tangan perhatian siswa bisa teralihkan (tidak malu) sehingga mudah berekspresi atau menyatakan perasaannya. Bahkan boneka bisa mendorong tumbuhnya fantasi atau imajinasi anak (Sulianto, 2014:96). Boneka berfungsi sebagai media perantara yang digunakan untuk melibatkan siswa agar mampu menangkap isi pembelajaran yang disampaikan oleh guru, dan berkesempatan untuk menggunakan boneka tangan dalam keterampilan berbicara. Oleh karena itu diadakan penelitian yang bertujuan untuk mengetahui bagaimana penerapan media boneka tangan dalam keterampilan berbicara pada mata pelajaran Bahasa Indonesia siswa dan apakah ada pengaruh signifikan penerapan media boneka tangan dalam keterampilan berbicara pada mata pelajaran Bahasa Indonesia siswa kelas IIIB di Madrasah Ibtidaiyah AtThayyibah Kecamatan Gambut.

\section{METODE PENELITIAN}

Jenis penelitian ini adalah penelitian lapangan (field rearch) dengan pendekatan kuantitatif. Menurut Sugiyono (2010:14) penelitian kuantitatif dapat diartikan sebagai metode penelitian yang berlandaskan pada filsafat positivisme, teknik pengambilan sampel pada umumnya dilakukan secara analisis data bersifat kuantitatif/statistic dengan tujuan untuk menguji hipotesis yang ditetapkan.

Desain penelitian yang digunakan dalam penelitian ini adalah desain One Group Pre test-Post test. Peneliti mengadakan pretest sebelum eksperimen dilakukan. Pretest yang diberikan adalah tes baku untuk mengukur keberhasilan pencapaian tujuan instruksional. Setelah perlakuan treatment diberikan maka dilakukan posttest (Kasiram, 2010:216). Desain ini membandingkan keadaan sebelum diberi perlakuan dan sesudah diberi perlakuan. Dengan demikian hasil perlakuan dapat diketahui lebih akurat. Seluruh siswa di kelas IIIB yang berjumlah 22 orang terdiri dari 12 orang laki-laki dan 10 orang perempuan adalah subjek dalam penelitian ini. Sedangkan objeknya adalah penerapan media boneka tangan dan pengaruhnya terhadap keterampilan berbicara pada mata pelajaran Bahasa Indonesia siswa kelas III B di MI At-Thayyibah Kecamatan Gambut. 
Adapun data tentang penerapan boneka tangan diperoleh melalui observasi. Sedangkan data tentang kemampuan awal dan kemampuan akhir diperoleh melalui tes yang diolah dengan menggunakan teknik analisis statistik uji Mann-Whitney (uji U).

\section{HASIL PENELITIAN DAN PEMBAHASAN}

1. Penyajian Materi Penerapan Media Boneka Tangan

a. Pertemuan Pertama

Guru menyampaikan materi mengenai pengertian bercerita. Guru menyampaikan unsur yang perlu diperhatikan saat praktiknya dalam keterampilan berbicara pada kegiatan bercerita yaitu memperhatikan ucapan (vokal), suara, ekspresi, penampilan, penghayatan yang sesuai dengan penilaian kemampuan berbicara berdasarkan faktor kebahasaan.

Setelah itu guru dan siswa bertanya jawab mengenai materi yang telah di sampaikan, sebelum diberlakukannya penerapan media boneka tangan pada pertemuan kedua.

b. Pertemuan Kedua

Guru menyajikan tentang materi cerita dengan menggunakan media boneka tangan, sesuai dengan rencana pelaksanaan pembelajaran yang telah dibuat. Pada pertemuan kedua penyajian materi dengan penerapan media boneka tangan. Kegiatan awal guru membuka pembelajaran dengan ucapan salam dan guru menunjuk salah satu siswa untuk memimpin berdoa bersama-sama, salah satu siswa membersihkan papan tulis sebelum pembelajaran dimulai. Guru tidak lupa menanyakan kabar siswa, memeriksa kehadiran siswa, serta guru memicu

keingintahuan siswa mengenai tujuan pembelajaran, guru menjelaskan tujuan pembelajaran, guru memotivasi siswa untuk terlibat secara aktif dalam proses belajar.

Pada kegiatan inti guru menyampaikan lanjutan materi unsur-unsur sebelum bercerita, memperkenalkan media boneka tangan kepada siswa, guru memberitahu kepada siswa mengenai rambu-rambu dalam memainkan boneka tangan sebelum siswa mencobanya pada kegiatan bercerita yaitu tanpa panggung (boneka cukup dua buah, cara memainkan boneka harus tepat jangan sampai lepas, cerita yang dibawakan cukup, intonasi wajib diperhatikan, waktu dan keterampilan berbicara dalam bercerita perlu diperhatikan.

Guru menjelaskan cara menggunakan media boneka tangan, guru mencontohkan bagaimana cara dalam menggunakan media boneka tangan dengan materi bercerita, yakni dengan cara memasukkan telapak tangan ke dalam boneka kemudian jari tangan bisa dijadikan pendukung gerakan tangan dan kepala boneka. Siswa memperhatikan materi yang diceritakan guru dengan media boneka tangan, guru memberi kesempatan kepada siswa untuk menanyakan hal yang belum mengerti. Siswa yang mengikuti pembelajaran sebanyak 22 orang siswa, setelah itu siswa dibagi menjadi 7 kelompok setiap kelompok terdiri dari 3-4 orang siswa dan masing-masing siswa memegang boneka tangan 1 buah. Jadi, dalam setiap kelompok ada 3-4 buah boneka tangan, kelompok yang maju kedepan kelas untuk bercerita pengalaman yang didengar dilihat berdasarkan materi. Guru memberi waktu 5 menit untuk menyusun dan berlatih bercerita. Selanjutnya siswa maju perkelompok untuk bercerita menggunakan media boneka tangan dengan keterampilan berbaicara. Sedangkan guru memantau kegiatan siswa dan membantu siswa yang kesulitan dalam proses belajar. Setelah itu guru bersama kelompok yang lain memberikan feedback tanggapan pada kelompok yang maju.

Pada pertemuan kedua ini siswa merasa senang, antusias, menjadi lebih aktif, dan bersemangat mengikuti pelajaran terlihat dari aktivitas dan respon siswa melalui observasi saat proses pembelajaran, karna cerita yang dibawakan katagori cerita yang menarik sesuai dengan anak Sekolah Dasar atau Madrasah Ibtidaiyah dikelas rendah, ditambah dengan adanya media boneka tangan sebagai alat peraga yang digunakan mendorong siswa tumbuhnya fantasi atau imajinasi dalam bercerita sehingga menyenangkan, dan siswa dapat 
menyampaikan cerita dengan keterampilan berbicara yang dimilikinya. Hal ini telihat pada saat siswa memainkan media boneka tangan berinteraksi dengan temannya sekelompok atau yang ada di kelas.

Siswa kelas III B MI At-Thayyibah antusias maju ke depan kelas untuk bercerita dengan menggunakan media boneka tangan tanpa disuruh guru, beberapa siswa yang terdiri dari 3-4 orang maju dengan percaya diri membuat kelompok yang lain ikut bersemangat untuk maju ke depan kelas. Pertemuan kedua ini jam ke-1 dan 2 sudah habis, kemudian dilanjutkan pada jam ke-3.

Pada akhir pembelajaran guru memberikan penguatan dan penjelasan singkat dan kesimpulan serta mengadakan tanya jawab kepada seluruh siswa tentang materi cerita untuk mengetahui tingkat perkembangan dan peningkatan pengetahuan serta pemahaman siswa. Guru meminta salah satu siswa menyimpulkan pembelajaran dan memberikan reward untuk kelompok yang bercerita bagus. Guru menutup pelajaran dengan membaca hamdallah serta mengingatkan siswa untuk mengulang pelajaran kembali di rumah.

Proses bagaimana penerapan media boneka tangan dalam keterampilan berbicara siswa kelas III B MI At-Thayyibah Kecamatan Gambut dapat dikatakan bahwa pelaksanaan keterampilan berbicara dengan menggunakan media boneka tangan sudah terlaksana dengan baik.

Berdasarkan penelitian penerapan media boneka tangan yakni perlu adanya ramburambu yang dilakukan dalam contoh memainkan boneka tangan melalui kegiatan bercerita sebelum siswa mencobanya tanpa panggung, yaitu: (boneka cukup dua buah, cara memainkan harus tepat jangan sampai lepas, cerita menggunakan boneka ke siswa cukup, intonasi wajib diperhatikan, dan waktu (Istiqomah, 2015:23). Pada tahap ini guru telah menyampaikan pada siswa untuk mengetahui rambu-rambu yang perlu diperhatikan saat menggunakan media boneka tangan dalam keterampilan berbicara. Hal ini dilakukan agar penerapan media boneka tangan dalam keterampilan berbicara terlaksana dengan baik. Guru juga telah mengenalkan pengertian bercerita, unsur-unsur yang perlu diperhatikan saat praktiknya menggunakan media boneka tangan dalam keterampilan berbicara melalui kegiatan bercerita, yaitu memperhatikan ucapan (vokal), suara, ekspresi penampilan penghayatan. (Chalimah, 14) Unsur tersebut sesuai dengan penilaian kemampuan berbicara berdasarkan faktor kebahasaan meliputi lafal, kosakata, struktur, dan nonkebahasaan meliputi materi kelancaran dan gaya. Berikut ini gambaran media boneka tangan yang digunakan pada kelas III B.

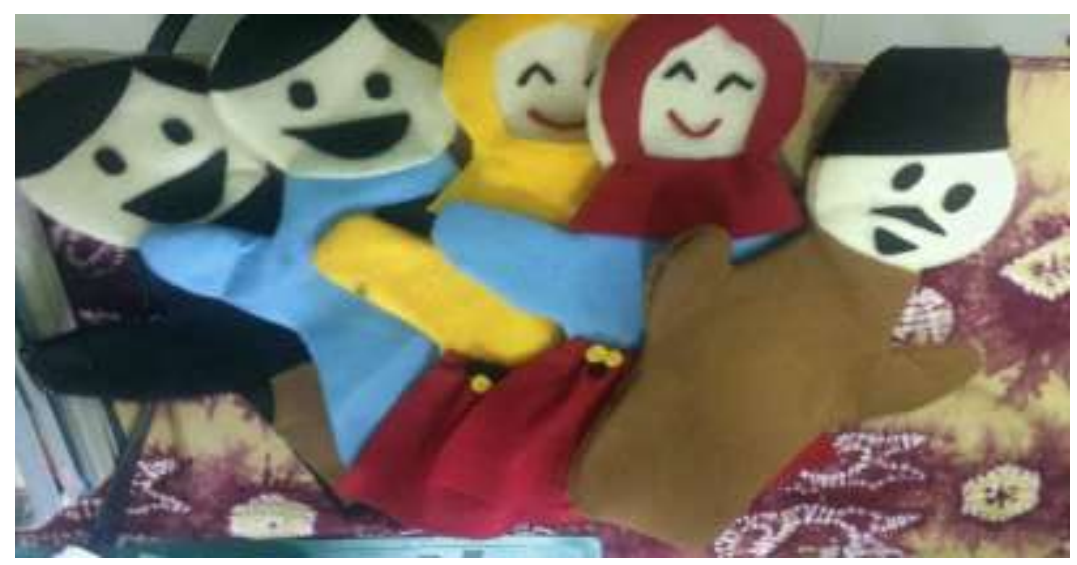

Gambar I Media Boneka Tangan Pada Kelas III B

Pada pertemuan kedua kegiatan ini terlihat siswa merasa sangat senang ketika diperkenalkan media boneka tangan, saat menggunakan atau sesudah pembelajaran, karena cerita yang dibawakan kategori cerita yang menarik sehingga siswa dapat mengembangkan 
imajinasi serta adanya aktivitas dalam suasana yang gembira. Meskipun ada beberapa siswa yang masih malu-malu dalam menggunakan media boneka tangan melalui kegiatan bercerita.

Berdasarkan pada proses penerapan media boneka tangan dalam keterampilan berbicara melalui kegiatan bercerita, yakni dapat mempermudah guru dalam proses pembelajaran, mempermudah pemahaman siswa sehingga munculnya keterampilan berbicara siswa ketika bercerita, dapat menarik minat dan perhatian siswa, kemudian membuat siswa antusias mengikuti pelajaran. Tidak hanya itu media boneka tangan ini membuat siswa bersemangat mengikuti pembelajaran serta mendorong siswa untuk aktif dalam pembelajaran, membuat siswa memahami materi dengan menggunakan media boneka tangan, dapat membuat siswa bekerjasama dengan baik dalam kelompok, walaupun saat pembelajaran media boneka tangan yang digunakan membuat kondisi dan situasi kelas menjadi sangat ramai tetapi tidak menjadi masalah karena kelas tetap terkontrol dengan baik oleh guru. Hal ini sejalan dengan teori "yang paling penting dari penggunaan boneka tangan dalam kegiatan pembelajaran adalah setiap siswa memperoleh pengalaman baru untuk meningkatkan kemampuan dalam keterampilan berbicara." (Gunarti, 2010:10).

2. Kemampuan Awal dan Akhir

Kemampuan awal siswa kelas III B MI At-Thayyibah untuk Keterampilan berbicara melalui kegiatan bercerita berada pada kualifikasi cukup berjumlah 4 orang (18.18\%), kurang ada 7 orang (31.81\%), dan amat kurang sebanyak 11 orang (50\%). Adapun deskripsi hasil pretest siswa terdapat pada tabel berikut:

Tabel 1 Deskripsi Hasil Awal Pretest Keterampilan Berbicara

\begin{tabular}{|c|c|}
\hline Nilai & Hasil Pretest \\
\hline Nilai tertinggi & 61,11 \\
\hline Nilai terendah & 33,33 \\
\hline Rata-rata & 45,45 \\
\hline Standar deviasi & 9,48 \\
\hline
\end{tabular}

Tabel $1 \mathrm{di}$ atas menunjukkan bahwa nilai rata-rata hasil awal keterampilan berbicara siswa di kelas III B yaitu 45,45 dan standar deviasinya adalah 9,48.

Kemampuan akhir siswa kelas IIIB MI At-Thayyibah untuk Keterampilan berbicara melalui kegiatan bercerita berada pada kualifikasi amat baik ada 4 orang (18.18\%), cukup berjumlah 2 orang $(9.09 \%)$, dan baik serta kurang masing-masing sebanyak 8 orang $(36.36 \%)$. Deskripsi hasil posttest siswa terdapat pada tabel berikut:

Tabel 2 Deskripsi Hasil Akhir Posttest Keterampilan Berbicara

\begin{tabular}{|c|c|}
\hline Nilai & Hasil posttest \\
\hline Nilai tertinggi & 94,44 \\
\hline Nilai terendah & 50,00 \\
\hline Rata-rata & 66,91 \\
\hline Standar deviasi & 12,05 \\
\hline
\end{tabular}

Tabel 2 di atas menunjukkan bahwa nilai rata-rata hasil akhir keterampilan berbicara di kelas IIIB yaitu 66,91 dan standar deviasinya 12,05.

Hasil uji prasyarat menunjukkan data berdistribusi normal tetapi tidak homogen. Lihat tabel sebagai berikut.

Tabel 3 Outpun SPSS Uji Homogenitas Hasil Awal dan Akhir Keterampilan Berbicara 
ANOVA

\begin{tabular}{|l|r|r|r|r|r|}
\hline & \multicolumn{1}{|c|}{$\begin{array}{c}\text { Sum of } \\
\text { Squares }\end{array}$} & df & $\begin{array}{c}\text { Mean } \\
\text { Square }\end{array}$ & \multicolumn{1}{c|}{ F } & Sig. \\
\hline Between & 5292,575 & 1 & 5292,575 & 47,087 &, 000 \\
Groups & 4720,752 & 42 & 112,399 & & \\
Within Groups & 10013,32 & 43 & & & \\
Total & 8 & & & & \\
\hline A $=0,05$ & \multicolumn{7}{|l}{} &
\end{tabular}

Nilai Sig. Atau signifikansi nilai probabilitas < 0,05 data berasal dari populasi yang mempunyai varians tidak serupa (Tidak Homogen). Sedangkan nilai Sig. Signifikasi atau nilai probabilitas $>0,05$ data berasal dari populasi yang mempunyai varians serupa (Homogen).

Berdasarkan tabel 3 di atas diketahui taraf signifikansi 0,05 didapatkan nilai Sig. Pada tabel diatas pada kolom Between Groups adalah 0,000 artinya $<0,05$ sehingga data dapat disimpulkan tidak homogen. Hal ini berarti hasil awal dan akhir keterampilan berbicara besifat tidak homogen.

\section{Uji U (Mann-Whitney)}

Data berdistribusi normal tetapi tidak homogen, maka uji beda yang digunakan adalah uji U sebagai alternatif penggunaan uji t jika prasyarat parametiknya tidak terpenuhi. Adapun output SPSS uji Mann-Whitney hasilnya dapat dilihat pada tabel sebagai berikut.

Tabel 4 Test Statistics(a)

\begin{tabular}{|c|c|}
\hline & $\begin{array}{c}\text { Hasil Keterampilan } \\
\text { Berbicara }\end{array}$ \\
\hline Mann-Whitney U & 45,500 \\
Wilcoxon W & 298,500 \\
Z & $-4,663$ \\
Asymp. Sig. (2-tailed) &, 000 \\
\hline
\end{tabular}

a Grouping Variable: PretestPosttest

Diketahui taraf signifikansi 0,05 didapatkan nilai Sig. Pada tabel Test Statistics(a) di kolom Asymp. Sig. (2-tailed) adalah 0,000 maka 0,000 < 0,05 sehingga $\mathrm{H}_{a}$ diterima dan $\mathrm{H}_{0}$ ditolak. Jadi dapat disimpulkan bahwa terdapat pengaruh yang signifikan penerapan media boneka tangan dalam keterampilan berbicara pada mata pelajaran Bahasa Indonesia siswa kelas III MI At-Thayyibah Kecamatan Gambut.

Simpulan di atas bisa diperkuat dengan melihat selisih antara nilai awal dengan nilai akhir. Dari tabel 1 dan 2 diketahui nilai hasil kemampuan akhir keterampilan siswa lebih tinggi dari pada sebelum diberi perlakuan. Berikut ini adalah gambaran diagram dari data hasil rata-rata pretest dan posttest siswa kelas III B. 


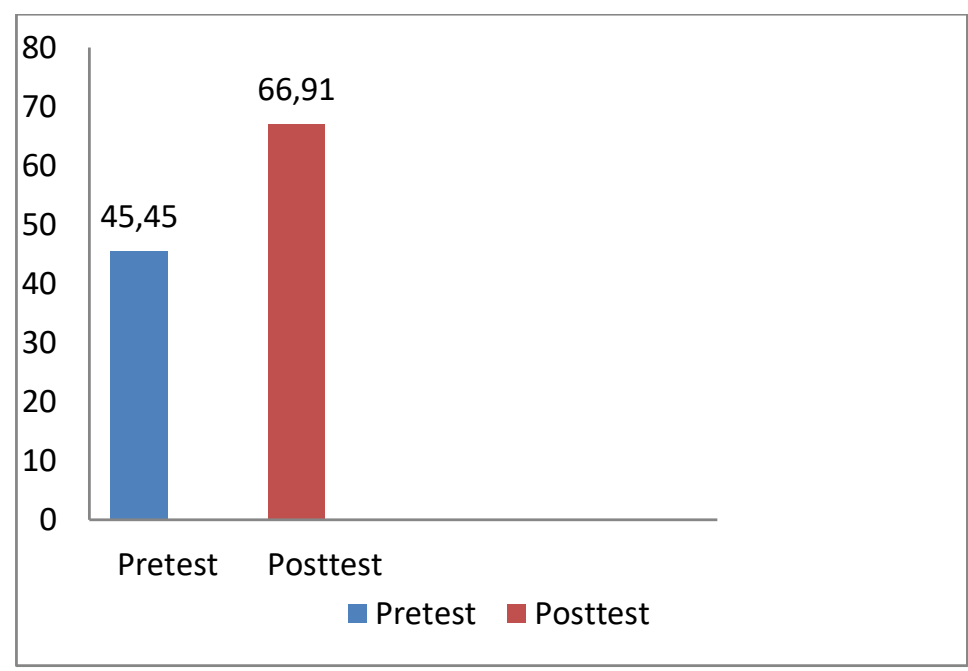

Gambar 2 Digram Penilaian Hasil Rata-rata pretest dan posttest Keterampilan Berbicara Siswa Kelas III B

Pada hasil nilai kemampuan awal pretest keterampilan berbicara nilai rata-rata adalah 45,45 termasuk dalam kualifikasi kurang dan nilai kemampuan akhir posttest keterampilan berbicara nilai rata-rata adalah 66,91 termasuk dalam kualifikasi baik. Nilai tersebut diperoleh sesuai dengan indikator keberhasilan yang berdasarkan pada dua faktor yaitu faktor kebahasaan dan nonkebahasaan. Faktor kebahasaan meliputi lafal, kosakata, dan struktur. Faktor nonkebahasaan meliputi, materi, kelancaran dan gaya.

Berdasarkan pada pertemuan pretest dalam keterampilan berbicara ketika siswa bercerita pada aspek lafal yaitu pelafalan fonem kurang jelas terpengaruh dialek (Bahasa Daerah) intonasi kurang tepat terdapat 22 siswa yaitu keseluruhan siswa masih terpengaruh. Pada aspek kosakata yaitu penguasaan kata-kata, ungkapan kurang tepat meskipun variatif terdapat 9 siswa, dan penguasaan kata-kata, ungkapan kurang tepat serta kurang variatif terdapat 13 siswa. Aspek struktur yaitu sekali-kali terdapat kesalahan struktur terdapat 7 siswa dan kesalahan struktur terjadi berulang-ulang terdapat 15 siswa.

Aspek materi yaitu isi cerita sesuai, dan kurang dipahami terdapat 8 siswa dan isi cerita kurang sesuai, dan sulit dipahami terdapat 14 siswa. Aspek kelancaran yaitu pembicara lancar, jelas dengan jeda kurang tepat terdapat 7 siswa dan pembicara sering tersendat, tidak jelas dan jeda tidak tepat terdapat 15 siswa. Aspek gaya yaitu gerakan, penampilan sopan, kurang luwes terdapat 17 siswa dan gerakan, penampilan kurang sopan, tidak luwes terdapat 5 siswa .

Pada pertemuan posttest ketika siswa bercerita pada aspek lafal yaitu pelafalan fonem jelas, tidak terpengaruh dialek, dan intonasi terdapat 3 siswa.

Pelafalan fonem jelas, tidak terpengaruh dialek, dan intonasi kurang jelas terdapat 14 siswa. Pelafalan fonem kurang jelas, terpengaruh dialek, dan intonasi kurang tepat terdapat 4 siswa. Aspek kosakata yaitu penguasaan kata-kata, ungkapan yang tepat dan variatif terdapat 4 siswa. Penguasaan kata-kata, ungkapan kurang tepat meskipun variatif terdapat 13 siswa. Penguasaan, ungkapan kurang tepat serta kurang variatif terdapat 5 siswa. Aspek struktur yaitu hampir tidak terjadi kesalahan struktur terdapat 11 siswa. Sekali-kali terdapat kesalahan struktur terdapat 8 siswa. Kesalahan struktur terjadi berulang-ulang terdapat 3 siswa.

Aspek materi yaitu isi cerita sesuai, dan mudah dipahami terdapat 3 siswa. Isi cerita sesuai, dan kurang dipahami terdapat 19 siswa. Isi cerita kurang sesuai, dan sulit dipahami terdapat 0 siswa. Aspek kelancara yaitu pembicaraan lancar sejak awal sampai akhir, jelas dengan jeda yang tepat terdapat 2 siswa. Pembicaraan lancar, jelas dengan jeda kurang tepat terdapat 9 siswa. Pembicaraan sering tersendat, tidak jelas dan jeda tidak tepat terdapat 11 siswa. 
Aspek gaya yaitu gerakan, penampilan sopan, luwes terdapat 2 siswa. Gerakan, penampilan sopan, kurang luwes terdapat 20 siswa. Gerakan, penampilan kurang sopan, tidak luwes terdapat 0 siswa. Berdasarkan hasil tersebut maka masih ada yang belum berhasil, akan tetapi terlihat adanya pengaruh dari aspek yang dicapai siswa setelah penerapan media boneka tangan dalam keterampilan berbicara.

Berdasarkan hasil yang diperoleh, maka menurut analisa peneliti terdapat adanya pengaruh penerapan media boneka tangan dalam keterampilan berbicara pada mata pelajaran Bahasa Indonesia kelas III B antara hasil kemampuan awal prestest keterampilan berbicara dengan hasil kemampuan akhir posttest keterampilan berbicara setelah penerapan media boneka tangan dalam keterampilan berbicara, terdapat adanya perubahan pada mulanya kurang aktif kemudian siswanya menjadi lebih aktif dan suasana menjadi menyenangkan.

Berdasarkan uraian di atas, dapat dipahami bahwa pelaksanaan pembelajaran dengan penerapan media boneka tangan dalam keterampilan berbicara ini ada terdapat pengaruh pada siswa kelas IIIB. Jadi, media ini dapat dijadikan guru sebagai media alternatif dalam melaksanakan pembelajaran karena dapat mempermudah guru dalam proses belajar dan dapat mempengaruhi keterampilan berbicara siswa dalam bercerita.

\section{PENUTUP}

Berdasarkan penelitian yang telah dilakukan dapat diambil beberapa kesimpulan sebagai berikut:

1. Penerapan media boneka tangan dalam keterampilan berbicara pada mata pelajaran bahasa Indonesia siswa kelas III di MI At-Thayyibah Kecamatan Gambut terlaksana dengan baik. Terlihat dari perencanaan, aktivitas guru dan siswa serta respon siswa terhadap media yang ditunjukkan oleh perhatian, antusias, semangat, keaktifan, memahami materi, kerjasama kelompok, sehingga siswa memperoleh pengalaman baru dalam meningkatkan keterampilan berbicara melalui kegiatan bercerita.

2. Berdasarkan hasil pengujian yang dilakukan dengan uji U Mann Whitney diperoleh nilai signifikansi sebesar 0,000 lebih kecil dari signifikansi 0,05 sehingga Ha diterima dan H0 ditolak. Jadi, terdapat pengaruh yang signifikan penerapan media boneka tangan dalam keterampilan berbicara pada mata pelajaran Bahasa Indonesia siswa kelas III di MI AtThayyibah Kecamatan Gambut.

Berdasarkan simpulan tersebut penulis merekomendasikan penggunaan media boneka tangan sebagai salah satu media alternatif dalam upaya meningkatkan pembelajaran bahasa.

\section{DAFTAR PUSTAKA}

Aqib, Zainal. (2013). Model-Model dan Strategi pembelajaran kontekstual (Inovatif), Bandung: Yrama Widya.

Chalimah, (2008). Peningkatan Keterampilan Bercerita dengan Pendekatan Kontekstual Teknik Pemodelan Melalui Media vcd, Pdf. Http://lib.unnr.ac.id/2187.

Darmadi, Kaswan dan Rita Nirbaya. (2008). Bahasa indonesia Untuk SD dan MI Kelas III. Jakarta:Pusat Perbukuan Departemen Pendidikan Nasional.

Ibrahim. (2012). "Teori-Teori Pembelajaran Bahasa Indonesia", www.teori-teoripembelajaran-bahasa.html.

Istiqomah, Titik Nur. (2015). Pengaruh penggunaan Media Boneka Tangan Terhadap Kemampuan Menyimak Dongeng Siswa Kelas II SD Negeri Kotagede 3 Yogyakarta, Yogyakarta, 2015. Http://eprints.uny.ac.id/25521/.

Kasiram, Moh. (2010). Metodologi Penelitian (Refleksi Pengembangan Pemahaman dan Penguasaan Metodologi Penelitian). Yogyakarta: UIN-MALIKI PRESS, Cet ke-II.

Sugiyono. (2014) Metode Penelitian Pendidikan. Bandung: Alfabeta. 
Sulianto, Joko, Mei Fita Asri Utari, Fitri Yulianti, Media Boneka Tangan Dalam Metode Bercerita untuk Menanamkan Karakter Positif Kepada Siswa Sekolah Dasar, dalam Jurnal Pendidikan Guru Sekolah Dasar Universitas PGRI Semarang, Vol. 15 No. 2, 2014, h. 95. Http://jurnal.ut.ac.id/index.php/JP/article/view/222.

Tarigan, Henry Guntur. (2008). Berbicara Sebagai Suatu Keterampilan Berbahasa. Bandung: Angkasa. Cet.1 Edisi Revisi.

W., Gunarti. (2010). Metode Pengembangan Perilaku dan Kemampuan Anak Usia Dini. Jakarta: Universitas Terbuka. 